\title{
Phylogeography indicates incomplete genetic divergence among phenotypically differentiated montane forest populations of Atlapetes albinucha (Aves, Passerellidae)
}

\author{
Alberto Rocha-Méndez', Luis A. Sánchez-González', Enrique Arbeláez-Cortés², \\ Adolfo G. Navarro-Sigüenza'
}

I Museo de Zoología, Facultad de Ciencias, Universidad Nacional Autónoma de México, Apartado Postal 70-399, México City 04510, México 2 Grupo de Estudios en Biodiversidad, Escuela de Biología, Facultad de Ciencias, Universidad Industrial de Santander. Carrera 27 Calle 9. Bucaramanga, Santander, Colombia

Corresponding author: Adolfo G. Navarro-Sigüenza (adolfon@ciencias.unam.mx)

Academic editor: Knud Jønsson | Received 1 August 2018 | Accepted 19 September 2018 | Published 19 December 2018

http://zoobank.org/5DE5COC5-669F-427A-9965-A91E70FF3F17

Citation: Rocha-Méndez A, Sánchez-González LA, Arbeláez-Cortés E, Navarro-Sigüenza AG (2018) Phylogeography indicates incomplete genetic divergence among phenotypically differentiated montane forest populations of Atlapetes albinucha (Aves, Passerellidae). ZooKeys 809: 125-148. https://doi.org/10.3897/zookeys.809.28743

\begin{abstract}
The White-naped Brushfinch (Atlapetes albinucha) comprises up to eight allopatric subspecies mainly identified by the color of the underparts (gray vs. yellow belly). Yellow and gray bellied forms were long considered two different species (A. albinucha and A. gutturalis), but they are presently considered as one polytypic species. Previous studies in the genus Atlapetes have shown that the phylogeny, based on molecular data, is not congruent with characters such as coloration, ecology, or distributional patterns. The phylogeography of $A$. albinucha was analyzed using two mitochondrial DNA regions from samples including 24 different localities throughout montane areas from eastern Mexico to Colombia. Phylogeographic analyses using Bayesian inference, maximum likelihood and haplotype network revealed incomplete geographic structure. The genetic diversity pattern is congruent with a recent process of expansion, which is also supported by Ecological Niche Models (ENM) constructed for the species and projected into three past scenarios. Overall, the results revealed an incomplete genetic divergence among populations of A. albinucha in spite of the species' ample range, which contrasts with previous results of phylogeographic patterns in other Neotropical montane forest bird species, suggesting idiosyncratic evolutionary histories for different taxa throughout the region.
\end{abstract}

Copyright Alberto Rocha-Méndez et al. This is an open access article distributed under the terms of the Creative Commons Attribution License (CC BY 4.0), which permits unrestricted use, distribution, and reproduction in any medium, provided the original author and source are credited. 


\section{Keywords}

allotypy, coalescent, Last Glacial Maximum, mtDNA, montane forest, Pleistocene, phylogeography, plumage differentiation

\section{Introduction}

Phylogeographic analyses of widespread Neotropical montane forest bird species have indicated different levels of geographic structure in the variation of mitochondrial DNA (mtDNA) among populations (Bonaccorso et al. 2008, Navarro-Sigüenza et al. 2008, Barrera-Guzmán et al. 2012, Ortíz-Ramírez et al. 2016). Deep genetic divergence may suggest a long history of geographic isolation, usually accompanied by phenotypic divergence, whereas a shallow genetic differentiation has been attributed to possible scenarios of either recent range expansions or recent divergence (CortésRodríguez et al. 2008, Arbeláez-Cortés et al. 2010).

The genus Atlapetes comprises a group of Neotropical finches inhabiting mainly humid montane forests from Mexico to northern Argentina (Paynter 1972, 1978), and has been considered one of the most species-rich clades (nearly 30 recognized species) among the New World passerines (Paynter 1972, 1978, Sánchez-González et al. 2015). Diversification in this group started about 5.2-3.2 Mya, and has probably occurred mainly due to changes in the range of montane forests related to the Pleistocene glacial cycles (Ricklefs and Latham 1992, Hooghiemstra et al. 2006, Sánchez-González et al. 2015). Atlapetes also provides a complex and intriguing case of evolutionary differentiation in plumage color (Paynter 1972, 1978, Remsen and Graves 1995). Most Atlapetes species have either yellow or gray underparts, which has led to the distinction of two main plumage patterns distributed in a "leapfrog" fashion along the Andes (Remsen 1984). Paynter $(1972,1978)$ included yellow and gray taxa in two different phylogenetic groups; a third group included yellow-plumaged species with bicolored crowns (A. albinucha, A. gutturalis, and A. pallidinucha). This phenotypically-based arrangement suggested that similarly plumaged species may have shared a common ancestor. However, Remsen and Graves (1995) proposed that some yellow and gray taxa may be representatives of the same species, suggesting that plumage differentiation patterns may be adaptive, as species with pale gray colors are generally found in drier and higher elevation habitats, whereas yellow-colored taxa are generally found in humid and lower elevations (Remsen and Graves 1995, García-Moreno and Fjeldså 1999).

Atlapetes albinucha (White-naped Brushfinch) is a widely distributed species found in montane regions from eastern Mexico to Colombia (AOU 1998, del Hoyo et al. 2011, Gill and Donsker 2015, Remsen et al. 2015). This species inhabits mainly humid and temperate montane forests (900 to $3000 \mathrm{~m}$ ), as well as upper tropical zones and edges of clearings of cloud forests (Dwight and Griscom 1921, Paynter 1978, Howell and Webb 1995, del Hoyo et al. 2011). Up to eight allopatric subspecies showing two well-differentiated plumage coloration patterns with clear geographic structure have been recognized (Figure 1, del Hoyo et al. 2011, Remsen et al. 2015, Gill and Donsker 2018). Phenotypic differentiation in this taxon led some researchers to consider such differenti- 


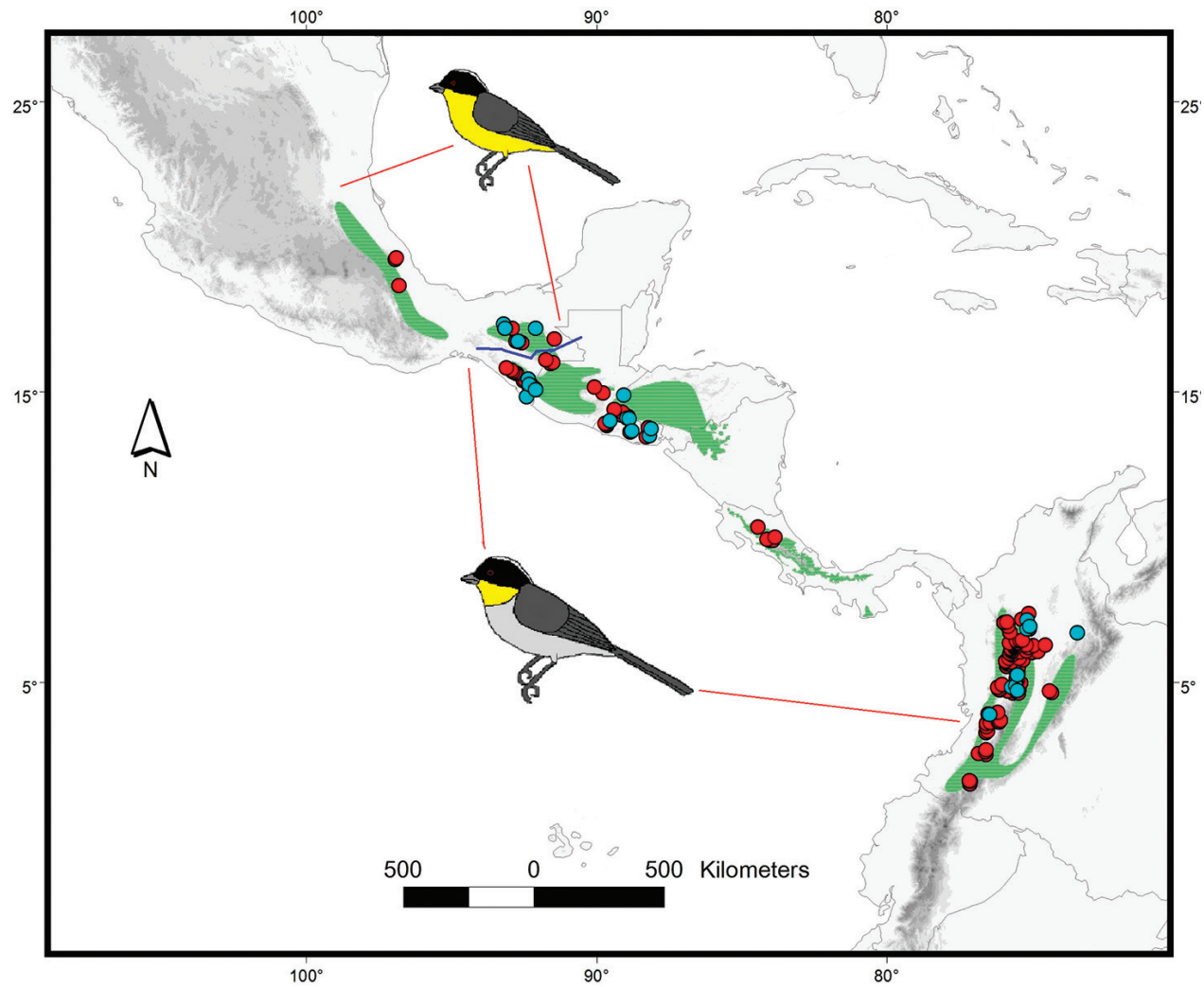

Figure I. Atlapetes albinucha distribution shown in green stapled lines, based on Sánchez-González et al. (2015) and Natureserve (http://natureserve.org). Blue dots depict tissue samples used in the present study. Red dots depict records of the species used to construct the distribution model. Bird pictures depict the geographic regions where color morphs are found. Blue line depicts the location of the putative distribution barrier of the morphs in Chiapas.

ated populations as two species (Dwight and Griscom 1921, Howell and Webb 1995, Navarro-Sigüenza and Peterson 2004) or as part of a polytypic species (Paynter 1978, Remsen and Graves 1995, AOU 1998, del Hoyo et al. 2011, Gill and Donsker 2015, Remsen et al. 2015). Differences between subspecies with pale-gray underparts are apparently largely clinal, and are based in subtle variations of size and color (Paynter 1978); while color morphs with yellow- and pale-gray underparts are allopatric (Figure 1), and their ranges are separated by the low valley of Río Grijalva $(1000 \mathrm{~m})$ in Chiapas (southeastern Mexico), where the two morphotypes are less than $100 \mathrm{~km}$ apart (Paynter 1978).

Paynter $(1972,1978)$ reviewed extensively the taxonomy and geographic variation in A. albinucha complex and suggested that plumage differentiation in these nearly parapatric populations were not indicative of a high genetic differentiation nor the product of ecological exclusion, but the result of a low river barrier, therefore implying isolation due to environmental factors as the main cause for this phenotypic differentiation. Current taxonomic schemes have adopted the proposal that $A$. albinucha represents a single 
polytypic species (Paynter 1978, Remsen and Graves 1995, AOU 1998, del Hoyo et al. 2011, Gill and Donsker 2015, 2018, Remsen et al. 2015). A study using mtDNA genetic analyses (Sánchez-González et al. 2015) at the genus level showed a phylogenetic reconstruction in which both yellow- and gray-plumaged birds in the $A$. albinucha complex were recovered mixed in a monophyletic group, sister to $A$. pileatus and well separated from the rest of Atlapetes, partially supporting the conclusions of Paynter (1978).

Here, using an extensive sampling for $A$. albinucha (39 individuals from 24 localities in four countries), we tested: a) if yellow- and gray-plumaged groups are reciprocally monophyletic, b) if there is phylogeographic structure in this widespread taxon across their range, and c) if past reconstructions of the environmental conditions were A. albinucha ranges at present indicate distributional changes that may be related with their genetic-geographic variation. These questions were approached using a mtDNA assessment of populations included within this complex, as well as environmental niche modelling analyses based on records of voucher specimens in biological collections.

\section{Materials and methods}

\section{Taxon sampling}

Tissue and blood samples of $A$. albinucha were obtained from different museum collections in Mexico, USA, and Colombia, spanning the whole distribution of the species (Table1, see Acknowledgements), except from two subspecies endemic to Panama (brunnescens and azuerensis). We also supplemented our study with two published sequences of Atlapetes pileatus, and two from Arremon brunneinucha to be used as outgroups (Klicka et al. 2007, DaCosta et al. 2009). Overall, we analyzed 39 samples from $A$. albinucha representing 24 localities from four countries, and four subspecies (Figure 1, Table 1).

\section{Laboratory procedures}

Extraction of DNA from tissue samples was carried out in two laboratory facilities in Mexico and Colombia using the DNeasy Blood \& Tissue Kit (Qiagen Inc., Valencia, CA) following manufacturer's protocols. We amplified two mtDNA genes fragments comprising the NADH dehydrogenase subunit 2 (ND2) and Cytochrome b (Cyt b), which have been shown to successfully assess phylogenetic relationships due to its high probability for tracking recent diversification events (Ball and Avise 1992, Avise 2000). We used primers L5215 (Hackett 1996) and H1064 (Drovetsky et al. 2004) for ND2. The Cyt b was amplified using primers L14990 (Kocher et al. 1989) and H15646 (Sorenson et al. 1999). PCR amplification reactions were performed in 12 to $25 \mu \mathrm{l}$ reaction mix containing $2 \mu \mathrm{l}$ of each primer, $2 \mu \mathrm{l}(-10 \mathrm{ng})$ of DNA and $6 \mu \mathrm{l}$ Readymix Redtaq (Sigma-Aldrich), or $6 \mu \mathrm{l}$ of Taq polymerase. PCR products were observed in a 
$1 \%$ agarose gel stained with Ethidium Bromide $(\mathrm{EtBr})$ or EZ-Vision. DNA sequencing was performed at the High Throughput Genomics Center of the University of Washington (USA), Macrogen Inc., Korea, and at the Servicio de Secuenciación y Análisis Molecular Universidad Nacional (SSiGMol, Colombia). Sequences were edited and aligned by eye using SEQUENCHER 5.4.6 (Gene Codes Corporation, Ann Arbor, MI USA). Mitochondrial origin for all of our sequences was corroborated in BLAST, through the NCBI server (https://blast.ncbi.nlm.nih.gov/Blast.cgi). Afterwards sequences were aligned using CLUSTALX 2.1 (Thompson et al. 1997) and inspected by eye. Newly generated sequences have been deposited in Gen Bank under accession numbers MH938455 to MH938526.

\section{Phylogeographic analyses}

We conducted analyses using an alignment with both mtDNA loci (ND2 and Cyt B) concatenated. Nucleotide substitution model parameters and partition schemes were estimated for each gene in PARTITIONFINDER (Lanfear et al. 2012), using the Bayesian Information Criterion (BIC) for model selection. Resultant partition schemes and model parameters were used for conducting a phylogenetic reconstruction using the Bayesian inference approach (BI) implemented in MR. BAYES 3.2 (Ronquist et al. 2011) using two independent searches running four Markov-Chains Montecarlo (temperature 0.2 ) for $10^{6}$ generations sampling every 1000 generations. Convergence across runs was evaluated using two methods: I) the examination of the standard deviation of split frequencies (with acceptance values $<0.01$ ); and II) by verification of parameter estimates in TRACER v1.6 (Rambaut et al. 2014), based on acceptable effective sample sizes (ESS values > 200). After checking for convergence, the first $25 \%$ of the generated trees were discarded as burn-in and the remaining $75 \%$ were kept to calculate posterior probabilities. In addition, we also conducted phylogenetic analyses using maximum likelihood (ML) criteria as implemented in RAXMLGUI 1.5b1 (Stamatakis 2006, 2014, Silvestro and Michalak 2012), using the GTRCAT model for nodal support via 1000 bootstrap iterations using the selected partitions. We considered nodes highly supported when bootstrap values were $>70 \%(\mathrm{ML})$ or when posterior probability values were $>90 \%(\mathrm{BI})$.

Divergence times were estimated through calculation of a maximum clade credibility tree (MCCT) using a Yule speciation process (Yule 1925, Gernhard 2008). Calibration of divergence time estimates was based on mutation rates proposed for the ND2 (0.013 subs/site/lineage/My, Arbogast et al. 2006) and Cyt b (0.01 subs/site/lineage/ My, Lovette 2004) loci. To test whether our dataset fits to a strict clock model or to a relaxed clock model, we performed selection tests through the stepping-stone method (Xie et al. 2011) as implemented in MrBAYES 3.2 (Ronquist et al. 2011). Given our partitioning model, the mean marginal likelihood of the strict clock (- Ln 5845.98) performed better than the relaxed clock (-Ln 5913.55). Therefore, chains were run under a strict clock with substitution models according to PARTITIONFINDER for 
Table I. Tissue and blood samples used in this study. Samples of $A$. albinucha species were grouped in five geographic groups: Northern Chiapas (NC, $\mathrm{n}=11$ ), Southern Chiapas (SC, $\mathrm{n}=11$ ), El Salvador (Sal, $\mathrm{n}$ = 7), Honduras (Hon, $\mathrm{n}=1$ ), and Colombia $(\mathrm{Col}, \mathrm{n}=9)$. One sample of Atlapetes pileatus tissue was also obtained and added to the analysis.

\begin{tabular}{|c|c|c|c|c|c|c|c|c|c|}
\hline \multirow[t]{2}{*}{$\begin{array}{c}\text { Sample } \\
\text { source }\end{array}$} & \multirow[t]{2}{*}{$\begin{array}{l}\text { Catalog } \\
\text { number }\end{array}$} & \multirow[t]{2}{*}{$\begin{array}{c}\text { Voucher } \\
\text { specimen }\end{array}$} & \multirow[t]{2}{*}{$\begin{array}{c}\text { State/ } \\
\text { Department }\end{array}$} & \multirow[t]{2}{*}{ Locality } & \multirow[t]{2}{*}{ Latitude } & \multirow[t]{2}{*}{ Longitude } & \multicolumn{2}{|c|}{$\begin{array}{c}\text { GenBank Accession } \\
\text { Number }\end{array}$} & \multirow[t]{2}{*}{$\begin{array}{l}\text { Geographic } \\
\text { Group }\end{array}$} \\
\hline & & & & & & & ND2 & Cyt b & \\
\hline \multirow{20}{*}{ 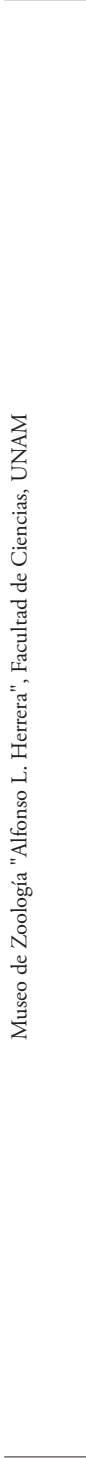 } & BONA 33 & BONA 33 & Chiapas & $\begin{array}{c}\text { Carretera estatal } \\
\text { Coapilla-Ocotepec } \\
\mathrm{km} 29 \text { a } 5.4 \mathrm{~km} \mathrm{~N} \mathrm{de} \\
\text { Coapilla }\end{array}$ & 17.31388 & -93.2 & MH938475 & MH938514 & $\mathrm{NC}$ \\
\hline & BONA 39 & BONA 39 & Chiapas & $\begin{array}{c}\text { Volcán Tacaná ladera, } \\
\text { vereda a Tapalapa, } \\
\text { Rancho Chiquihuite }\end{array}$ & 15.0666 & -92.08333 & MH938476 & MH938515 & SC \\
\hline & BONA 52 & BONA 52 & Chiapas & $\begin{array}{c}\text { Volcán Tacaná ladera, } \\
\text { vereda a Tapalapa, } \\
\text { Rancho Chiquihuite }\end{array}$ & 15.0666 & -92.08333 & MH938474 & MH938513 & SC \\
\hline & BONA 89 & BONA 89 & Chiapas & $\begin{array}{c}\text { Volcán Tacaná ladera, } \\
\text { vereda a Tapalapa, } \\
\text { Rancho Chiquihuite }\end{array}$ & 15.0666 & -92.08333 & MH938479 & - & SC \\
\hline & BONA 94 & BONA 94 & Chiapas & $\begin{array}{c}\text { Volcán Tacaná ladera, } \\
\text { vereda a Tapalapa, } \\
\text { Rancho Chiquihuite }\end{array}$ & 15.0666 & -92.08333 & MH938477 & MH938516 & SC \\
\hline & BMM 577 & BMM 577 & Chiapas & $\begin{array}{c}6 \mathrm{~km} \text { NE de Pueblo } \\
\text { Nuevo; camino a } \\
\text { Aurora-Ermita }\end{array}$ & 17.18333 & -92.08333 & MH938478 & MH938517 & $\mathrm{NC}$ \\
\hline & BMM 582 & BMM 582 & Chiapas & $\begin{array}{c}6 \mathrm{~km} \text { NE de Pueblo } \\
\text { Nuevo; camino a } \\
\text { Aurora-Ermita }\end{array}$ & 17.18333 & -92.08333 & MH938464 & MH938503 & $\mathrm{NC}$ \\
\hline & BMM 834 & BMM 834 & Chiapas & $\begin{array}{c}\text { Volcán Tacaná ladera, } \\
\text { vereda a Tapalapa, } \\
\text { Rancho Chiquihuite }\end{array}$ & 15.0666 & -92.08333 & KM360517 & MH938498 & SC \\
\hline & $\begin{array}{l}\text { MOL } \\
13001\end{array}$ & $\begin{array}{l}\mathrm{MOL} \\
13001\end{array}$ & Chiapas & $\begin{array}{c}\text { San Nicolás } \\
\text { Buenavista, Cerro } \\
\text { Huitepec }\end{array}$ & 16.73805 & -92.68805 & MH938468 & MH938507 & $\mathrm{NC}$ \\
\hline & $\begin{array}{l}\text { MOL } \\
13061\end{array}$ & $\begin{array}{l}\text { MOL } \\
13061\end{array}$ & Chiapas & $\begin{array}{c}\text { San Nicolás } \\
\text { Buenavista, Cerro } \\
\text { Huitepec }\end{array}$ & 16.73805 & -92.68805 & MH938467 & MH938506 & $\mathrm{NC}$ \\
\hline & $\begin{array}{l}\text { MOL } \\
13130\end{array}$ & $\begin{array}{l}\text { MOL } \\
13130\end{array}$ & Chiapas & $\begin{array}{c}\text { San Nicolás } \\
\text { Buenavista, Cerro } \\
\text { Huitepec }\end{array}$ & 16.73805 & -92.68805 & MH938466 & MH938505 & $\mathrm{NC}$ \\
\hline & SIT 105 & SIT 105 & Chiapas & $\begin{array}{l}\text { CarreteraCopainalá- } \\
\text { Ocotepec km } 38 \text { a } \\
95.5 \text { km N de Coapilla }\end{array}$ & 17.16891 & -93.14533 & MH938481 & MH938519 & $\mathrm{NC}$ \\
\hline & SIT 146 & SIT 146 & Chiapas & Coapilla a $6.5 \mathrm{~km} \mathrm{~N}$ & 17.17413 & -93.14636 & MH938463 & MH938502 & $\mathrm{NC}$ \\
\hline & SIT 147 & SIT 147 & Chiapas & Coapilla a $6.5 \mathrm{~km} \mathrm{~N}$ & 17.17413 & -93.14636 & MH938472 & MH938511 & $\mathrm{NC}$ \\
\hline & SIT 157 & SIT 157 & Chiapas & Coapilla a $6.5 \mathrm{~km} \mathrm{~N}$ & 17.17413 & -93.14636 & MH938462 & MH938501 & $\mathrm{NC}$ \\
\hline & SIT 158 & SIT 158 & Chiapas & Coapilla a $6.5 \mathrm{~km} \mathrm{~N}$ & 17.17413 & -93.14636 & MH938480 & MH938518 & $\mathrm{NC}$ \\
\hline & EAGT 806 & EAGT 806 & Chiapas & $\begin{array}{c}\text { Cerro Mozotal, en } \\
\text { la cima }\end{array}$ & 15.4294 & -92.3411 & MH938458 & MH938495 & SC \\
\hline & EAGT 817 & EAGT 817 & Chiapas & $\begin{array}{c}\text { Cerro Mozotal, en } \\
\text { la cima }\end{array}$ & 15.4294 & -92.3411 & MH938457 & MH938494 & SC \\
\hline & EAGT 844 & EAGT 844 & Chiapas & $\begin{array}{l}\text { Cerro Boqueron, en } \\
\text { la cima }\end{array}$ & 15.23541 & -92.30463 & MH938473 & MH938512 & SC \\
\hline & ZRH 407 & ZRH 407 & Chiapas & $\begin{array}{l}\text { Cerro Mozotal, en } \\
\text { la cima }\end{array}$ & 15.4294 & -92.3411 & MH938460 & MH938499 & SC \\
\hline \multirow{4}{*}{ 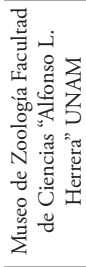 } & 130332 & 130332 & Chiapas & $\begin{array}{c}\text { Reserva Ecológica el } \\
\text { Triunfo }\end{array}$ & 14.81278 & -92.40594 & MH938456 & MH938492 & SC \\
\hline & 130345 & 130345 & Chiapas & $\begin{array}{c}\text { Reserva Ecológica el } \\
\text { Triunfo } \\
\end{array}$ & 14.81278 & -92.40594 & KM360516 & MH938493 & SC \\
\hline & QRO0272 & QRO0272 & Querétaro & El Pemoche & 21.2263 & -99.109694 & MH938455 & MH938491 & \\
\hline & OVMP227 & OVMP227 & Jalisco & - & - & - & FJ547292 & FJ547251 & \\
\hline
\end{tabular}




\begin{tabular}{|c|c|c|c|c|c|c|c|c|c|}
\hline \multirow[t]{2}{*}{$\begin{array}{l}\text { Sample } \\
\text { source }\end{array}$} & \multirow[t]{2}{*}{$\begin{array}{l}\text { Catalog } \\
\text { number }\end{array}$} & \multirow[t]{2}{*}{$\begin{array}{c}\text { Voucher } \\
\text { specimen }\end{array}$} & \multirow[t]{2}{*}{$\begin{array}{c}\text { State/ } \\
\text { Department }\end{array}$} & \multirow[t]{2}{*}{ Locality } & \multirow[t]{2}{*}{ Latitude } & \multirow[t]{2}{*}{ Longitude } & \multicolumn{2}{|c|}{$\begin{array}{c}\text { GenBank Accession } \\
\text { Number }\end{array}$} & \multirow[t]{2}{*}{$\begin{array}{c}\text { Geographic } \\
\text { Group }\end{array}$} \\
\hline & & & & & & & ND2 & Cyt b & \\
\hline \multirow{7}{*}{ 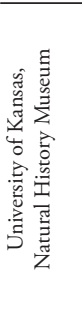 } & EAGT 21 & KU 4907 & San Miguel & San Miguel & 13.48138 & -88.1775 & GU377050 & MH938497 & Sal \\
\hline & EAGT 74 & KU 5017 & Chalatenango & $\begin{array}{l}\text { Concepción } \\
\text { Quezaltepec }\end{array}$ & 14.08333 & -88.95 & MH938459 & MH938496 & Sal \\
\hline & OK 56 & KU 4961 & Morazan & Chilanga & 13.71666 & -88.11666 & MH938465 & MH938504 & Sal \\
\hline & $\begin{array}{c}\text { CMZF } \\
120\end{array}$ & KU 6448 & San Vicente & Nuevo Tepetitán & 13.64527 & -88.78416 & MH938471 & MH938510 & Sal \\
\hline & LR 58 & KU 7704 & Chalatenango & La Laguna & 14.0666 & -88.8666 & MH938470 & MH938509 & Sal \\
\hline & SLA 165 & KU 7775 & San Vicente & Nuevo Tepetitán & 13.64527 & -88.78416 & MH938461 & MH938500 & Sal \\
\hline & MBR 6584 & KU 9400 & Santa Ana & Metapán & 13.98333 & -89.5333 & MH938469 & MH938508 & Sal \\
\hline \multirow{9}{*}{ 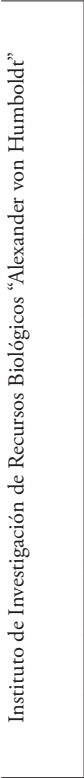 } & $\begin{array}{c}\text { IAvH- } \\
\text { CT-01158 }\end{array}$ & $\begin{array}{l}\text { IAvH- } \\
11694\end{array}$ & Pereira & $\begin{array}{c}\text { Parque regional } \\
\text { Ucumarí Entre Peńa } \\
\text { Bonita y Peńas Blancas }\end{array}$ & 4.709233 & -75.4907 & MH938483 & MH938521 & Col \\
\hline & \begin{tabular}{|c|} 
IAvH- \\
CT-01726
\end{tabular} & $\begin{array}{l}\text { IAvH- } \\
11946\end{array}$ & Aranzazu & $\begin{array}{l}\text { Vereda El Laurel, } \\
\text { Cuenca Alta del Río } \\
\text { Hacienda Termopilas }\end{array}$ & 5.230944 & -75.48841 & MH938484 & - & $\mathrm{Col}$ \\
\hline & \begin{tabular}{|c|} 
IAvH- \\
CT-02391
\end{tabular} & $\begin{array}{l}\text { IAvH- } \\
12363\end{array}$ & Yotoco & Yotoco & 3.87975 & -76.443 & MH938485 & MH938522 & $\mathrm{Col}$ \\
\hline & \begin{tabular}{|c|} 
IAvH- \\
CT-04519
\end{tabular} & $\begin{array}{l}\text { IAvH- } \\
13101\end{array}$ & $\begin{array}{c}\text { Santa Rosa de } \\
\text { Cabal }\end{array}$ & $\begin{array}{l}\text { Vereda La Linda, } \\
\text { Parque Municipal de } \\
\text { Campoalegre }\end{array}$ & 4.8675 & -75.54666 & MH938486 & MH938523 & Col \\
\hline & \begin{tabular}{|c|} 
IAvH- \\
CT-04835
\end{tabular} & $\begin{array}{c}\text { IAvH- } \\
\text { CT-04835 }\end{array}$ & Anorí & $\begin{array}{c}\text { Vereda Santa } \\
\text { Gertrudis, Finca } \\
\text { La Estrella margen } \\
\text { derecha de la Quebrada } \\
\text { Santa Gertrudis }\end{array}$ & 7.135444 & -75.15527 & MH938487 & - & $\mathrm{Col}$ \\
\hline & \begin{tabular}{|c|} 
IAvH- \\
CT-07844
\end{tabular} & $\begin{array}{c}\text { IAvH- } \\
\text { CT-07844 }\end{array}$ & Amalfi & $\begin{array}{c}\text { Vereda Cajamarca, } \\
\text { Finca Canales Cuenca } \\
\text { de la quebrada } \\
\text { Cajamarca }\end{array}$ & 6.8235 & -75.15527 & MH938488 & MH938524 & $\mathrm{Col}$ \\
\hline & \begin{tabular}{|c|} 
IAvH- \\
CT-09344
\end{tabular} & $\begin{array}{c}\mathrm{ICN} \\
34591 \\
\end{array}$ & Amalfi & $\begin{array}{c}\text { Vereda El Encanto, La } \\
\text { Secreta }\end{array}$ & 6.909167 & -75.0766 & MH938489 & MH938525 & $\mathrm{Col}$ \\
\hline & \begin{tabular}{|c|} 
IAvH- \\
CT-09695
\end{tabular} & $\begin{array}{c}\text { IAvH- } \\
\text { CT-09695 }\end{array}$ & Pereira & P. Ucumarí, La Pastora & 4.814278 & -75.69455 & MH938490 & MH938526 & $\mathrm{Col}$ \\
\hline & \begin{tabular}{|c|} 
IAvH- \\
CT-18248
\end{tabular} & $\begin{array}{c}\mathrm{ICN} \\
38086\end{array}$ & Santander & $\begin{array}{c}\text { Serranía de los } \\
\text { Yariguies, Carmen de } \\
\text { Chucurí }\end{array}$ & 6.68333 & -73.4333 & MH938482 & MH938520 & $\mathrm{Col}$ \\
\hline \multirow[b]{2}{*}{ 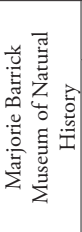 } & GAV 1374 & $\begin{array}{c}\text { MBM } \\
6640\end{array}$ & Copán & $\begin{array}{c}\text { Copán Ruinas, } 10 \\
\text { km ENE }\end{array}$ & 14.86667 & -89.05 & GU377047 & DQ459625 & Hon \\
\hline & DAB1706 & $\begin{array}{c}\text { MBM } \\
4600\end{array}$ & Managua & $\begin{array}{c}\text { Chocoyero, Volcán } \\
\text { Mombacho, 48km SE } \\
\text { Managua }\end{array}$ & 11.829 & -85.963 & EF529823 & EF529932 & \\
\hline
\end{tabular}

$10^{6}$ generations and discarded the first $25 \%$ as burn-in. Stationarity was analyzed with TRACER v1.6 (Rambaut et al. 2014). Mean heights and $95 \%$ credibility interval values for node estimates were generated in TREEANNOTATOR v1.8.4 (Drummond et al. 2012) with a posterior probability limit of 0.6. Trees were visualized in FIGTREE v1.4.2 (http://tree.bio.ed.ac.uk/software/figtree/).

Finally, to complement the visualization of the relationships among haplotypes, a haplotype network was constructed using NETWORK 4.6.1.1 (Fluxus Engineering, www.fluxus-engineering.com), through a Median-joining method, assigning equal weights to all variable sites and an epsilon parameter with default values $(\varepsilon=0)$. This method estimates evolutionary relationships among sequences when divergences are recent (Crandall and Templeton 1996, Bandelt et al. 1999). 


\section{Population genetic structure and historical demographic analyses}

To analyze the molecular information in the framework of population genetics, we clustered individuals of $A$. albinucha into four groups considering subspecific membership as well as geographic proximity and evidence of montane forest continuity (Table 1): (I) Northern Chiapas (NCh, $\mathrm{n}=11$; subspecies albinucha), (II) Southern Chiapas (SCh, $\mathrm{n}=11$; subspecies griseipectus), (III) El Salvador (Sal, $\mathrm{n}=7$; subspecies griseipectus), Honduras (Hon, $\mathrm{n}=1$; subspecies fuscipygius), and (IV) Colombia (Col, $\mathrm{n}=9$; subspecies gutturalis). For each group, genetic diversity was assessed through the estimation of haplotype diversity (Hd), and nucleotide diversity $(\pi)$ in ARLEQUIN 3.1 (Excoffier et al. 2005).

To test if there is evidence of genetic structure among the four geographic groups, we performed a hierarchical analysis of molecular variance (AMOVA) using pairwise differences. In addition, to test if phenotypic divergence is related to genetic structure we also performed an AMOVA between gray-plumaged subspecies and yellowplumaged subspecies. Genetic divergence between groups was also measured using $F_{S T}$ fixation index values (Wright 1931, 1978), which were interpreted following the guidelines in Hartl and Clark (1997). All tests were performed with ARLEQUIN 3.1 (Excoffier et al. 2005); and their significance was assessed using 1000 permutations.

To test for evidence of recent demographic changes in A. albinucha, we estimated demographic dynamics experienced by the whole taxon through the calculation of neutrality tests corresponding to Fu's $\mathrm{F}_{S}$ statistic ( $\mathrm{Fu}$ 1997) and Tajima's D statistic (Tajima 1989). Significance of these tests ( $<0.02$ in the case of the $F_{S}$ statistic) was calculated by developing 1000 simulations using ARLEQUIN 3.1. Evidence of historical signatures of fluctuations in population size was also examined through a Bayesian skyline plot model on the Maximum Clade Credibility Tree (MCCT), as implemented in BEAST v1.8.4 (Drummond et al. 2012), using a coalescent-based estimation of population size changes over time with MCMC sampling procedure (Ho and Shapiro 2011, Houston et al. 2014).

\section{Analysis of the historic range using ecological niche models}

We tested the hypotheses that the ecological/environmental conditions in which $\mathrm{A}$. albinucha ranges at present may have allowed for population connectivity at least since the Last Interglacial (120,000 ya) using ecological niche models (ENM). We compiled a total of 475 geographical records, representing 176 localities, of the species through the Global Biodiversity Information Facility (GBIF, http://www.gbif.org) and museum vouchers (see Acknowledgements). GBIF records were filtered for elimination of both duplicates and records lacking geographic data. ENMs were obtained using 19 bioclimatic variables with a cell resolution of 2.5 arc-minutes (ca. $4.5 \mathrm{~km}^{2}$ ) generated by the Community Climate System Model (CCSM) downloaded through WorldClim (http:// 
www.worldclim.org/bioclim; Hijmans et al. 2005). ENM models were obtained and evaluated in MAXENT 3.3.3 (Phillips et al. 2006), whose algorithms have been used to transfer present niche space conditions into past scenarios (120,000 ya-present). Past ENM reconstructions were based on the CCSM scenarios for the LIG (ca. 120,000 ya), Mid-Holocene (MHCO, ca. 6,000 ya), and LGM (ca. 22,000 ya). CCSM scenarios were preferred over other models as it has been proposed that global cooling conditions are not overestimated (Fernández-Mazuecos and Vargas 2013, Harrison et al. 2014), therefore representing a conservative hypotheses of humid montane forests connectivity. MAXENT parameters were run as follows: Ten-thousand random points within extreme coordinates $22 \mathrm{~N}-105 \mathrm{~W}, 20 \mathrm{~S}-62 \mathrm{~W}$ were generated to serve as background data to encompass mostly montane habitats in the Neotropics, 50 bootstrap replicates with a maximum iteration value of 5000 , and a random test percentage of 25 with a 10 percentile training presence threshold rule (Warren and Seifert 2011, Baldwin 2009). To evaluate the predictive ability of the generated distribution models we implemented two model validations using the ROC plot method. As a first evaluation measure, we used the value for the area under the receiver operating characteristic curve (AUC), which can be used as a measure of the model's overall performance; for a second model validation we used PARTIALROC (P-ROC) analysis (Barve 2008, Peterson et al. 2008), which generates ratios that provide a measurement of the correct identification of presences against the total area predicted (Mendoza-González et al. 2016). ENM models were visualized in ARCMAP 10 (ESRI 2010).

\section{Results}

\section{Phylogeography}

Phylogenetic reconstruction analyses were conducted using the substitution models $\mathrm{HKY}+\mathrm{I}+\mathrm{G}$ for the first position of ND2 and the second position of Cyt b, F81+I for $\mathrm{ND} 2$ second position and third Cyt $\mathrm{b}$ position and HKY+G for the third and first positions of ND2 and Cyt b respectively. Both phylogenetic reconstruction methods (ML and IB) rendered similar topologies. The Bayesian tree topology (Figure 2A) recovered all of the $A$. albinucha samples in a monophyletic group (as suggested previously by Sánchez-González et al. 2015) showing two major well-supported clades (0.99 and 1.00 ) but moderate bootstrap support (0.56 and 0.66). One clade, including only gray-plumaged birds, grouped all of the individuals from the Central Andes of Colombia, as well as two individuals from southern Chiapas, in Mexico (Reserva Ecológica El Triunfo). The other clade included both yellow- and gray-plumaged birds from Mexico and Central American, as well as one Colombian sample from Serranía de los Yariguies, Santander (IAvH-CT 18248). No one of the four subspecies included was monophyletic according to the two mtDNA loci analyzed, and the yellow- and grayplumaged groups were neither reciprocally monophyletic. Therefore, no clear phylogeographic structure was recovered from our analysis (Figure 2). 


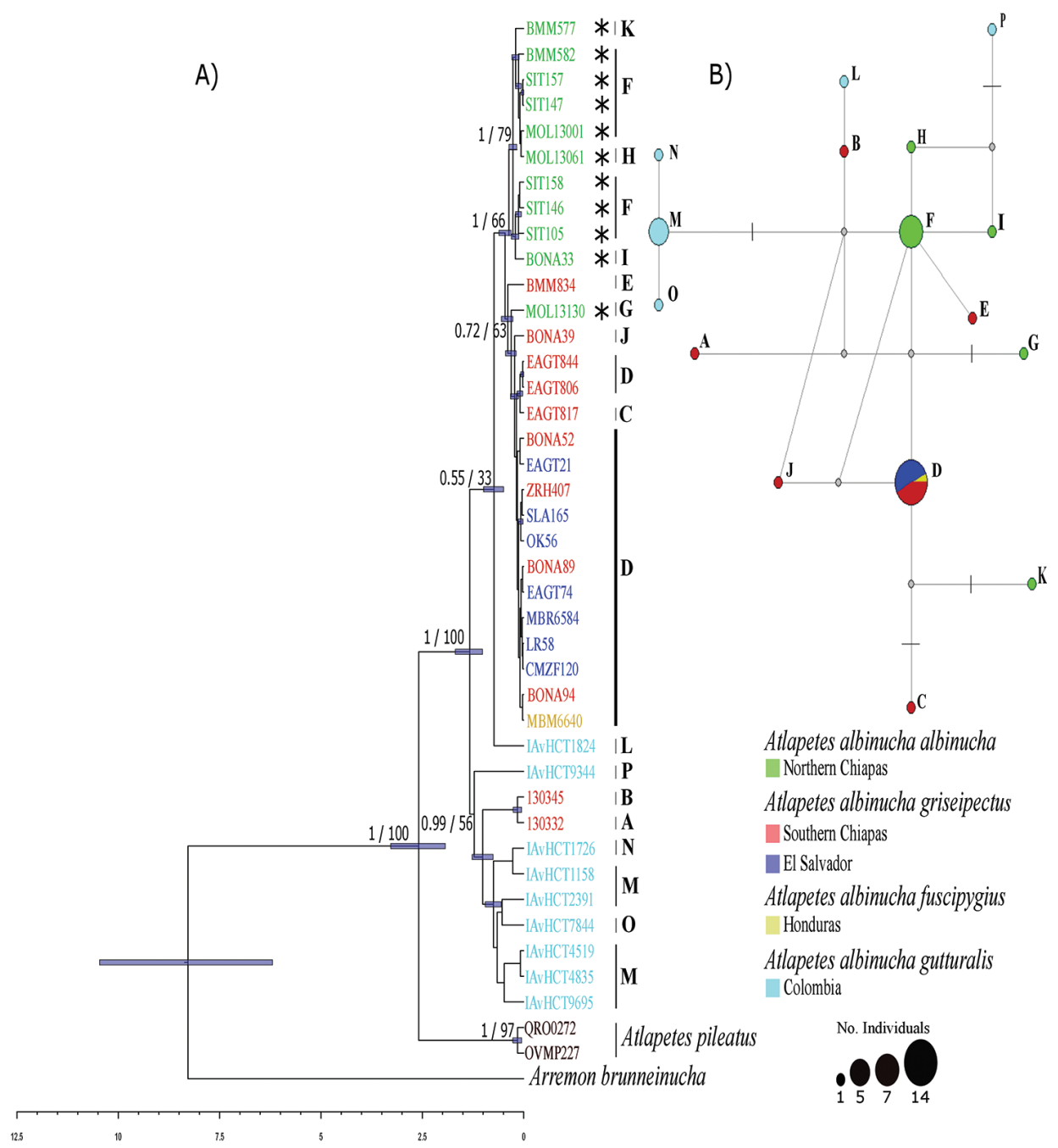

Figure 2. A Dated Bayesian maximum clade credibility tree showing phylogenetic relationships among members of Atlapetes albinucha species. Node bars depict 95\% HDP interval, scale bar represents millions of years. Nodal values above branches indicate posterior probabilities/ bootstrap supports of BI/ML. Capital letters depict haplotypes. An asterisk $\left(^{*}\right)$ indicate birds representing yellow morphs B Median-joining haplotype network for the concatenated dataset. Each color depicts the geographic provenance of samples: green-northern Chiapas (subspecies albinucha), red-southern Chiapas (subspecies griseipectus), blue-El Salvador (subspecies griseipectus), yellow-Honduras (subspecies fuscipygius) and light blue-Colombia (subspecies gutturalis). Each branch represents a single nucleotide change, transversal black lines along branches depict the occurrence of three mutations. Gray dots indicate median vectors inferred for the data. 


\section{Population genetic structure and demographic history}

Overall, genetic diversity values for the geographic groups showed a low nucleotide diversity $(\pi<0.008)$, but high haplotype diversity ( $\mathrm{Hd}>0.71$; Table 2$)$. The AMOVA between geographic groups indicated that genetic variation was explained (almost equally) by both differences among populations (50.7\%), as well as by variation within groups (49.2\%, Table 3). Comparisons among pairs of geographic groups using $F_{S T}$ values revealed very high genetic differentiation between El Salvador and northern Chiapas $\left(F_{S T}\right.$ $=0.71412)$, but lower differentiation was among El Salvador and southern Chiapas $\left(F_{S T}\right.$ $=0.04556)$; the remaining $F_{S T}$ values indicated moderate genetic differentiation $\left(F_{S T}\right.$ between 0.4 and 0.7$)$. AMOVA between gray- and yellow-plumaged morphs showed that most of the variance occurs within groups $(64.5 \%)$, paralleling the results of the phylogenetic analysis that showed that both phenotypes are not reciprocally monophyletic.

The haplotype network showed three non-shared high frequency haplotypes: one including most samples from Colombia (gutturalis); a second one where most samples from northern Chiapas (albinucha) are located; and a third high frequency haplotype that was shared by most samples corresponding to northern Central America, which includes subspecies griseipectus and fuscipygius (Figure 2B).

Despite relatively low bootstrap values, molecular dating of the divergence between $A$. albinucha and $A$. pileatus yielded a time estimate during the Late PlioceneEarly Pleistocene about 2.5 Mya (HPD range 1.94-3.28 Mya), whereas differentiation between major clades of $A$. albinucha apparently occurred around 1.5 Mya (HDP range 1.01-1.61 Mya), during the Early Pleistocene (Figure 2A).

Historical demography in A. albinucha as estimated from the Tajima's D and Fu's $\mathrm{F}_{\mathrm{S}}$ tests showed in most cases negative values, except for the $\mathrm{F}_{\mathrm{S}}$ in the Colombian population. Both demographic tests did not depart from neutrality given that values were not significant neither at the species nor at the geographic group level; therefore, demographic fluctuations are difficult to suggest based on these values (Table 2). Bayesian skyline plot indicated an overall pattern of population stability throughout the Pleistocene at the species level, however, a fluctuation near the present (ca. 100,000 ya), suggests a population bottleneck followed by rapid population expansion (Figure 3), thus paralleling results from the genetic diversity analyses.

Table 2. Genetic diversity measures and demographic fluctuation measured at the species and population level within the concatenated data set. Abbreviations: N Sample size, Hd Haplotype diversity, $\pi$ nucleotide diversity, SD standard deviation.

\begin{tabular}{lccccc}
\hline & $\mathbf{N}$ & $\mathbf{H d}(\mathbf{S D})$ & $\boldsymbol{\pi}(\mathbf{S D})$ & Tajima's D & $\mathbf{F u}^{\prime} \mathbf{s} \mathbf{F}_{\mathbf{s}}$ \\
\hline Northern Chiapas & 11 & $0.982(0.046)$ & $0.00264(0.0015)$ & -1.49107 & -2.654 \\
Southern Chiapas & 11 & $0.727(0.144)$ & $0.007674(0.0041)$ & -1.037 & -0.905 \\
El Salvador & 7 & $0.714(0.181)$ & $0.00077(0.00028)$ & -1.023 & -0.538 \\
Colombia & 9 & $0.722(0.159)$ & $0.004313(0.0026)$ & -1.37093 & 0.81161 \\
Honduras & 1 & - & - & - & - \\
\hline Total & 39 & $0.835(0.047)$ & $0.00652(0.0007)$ & -1.267 & -5.08 \\
\hline
\end{tabular}


Table 3. Analyses of molecular variance (AMOVA) between gray- and yellow-plumaged morphs and between geographical groups.

\begin{tabular}{lcccc}
\hline \multirow{2}{*}{ Source of variation } & \multicolumn{4}{c}{ AMOVA: gray- and yellow-plumaged morphs } \\
& Sum of squares & Variance components & Percentage of variation & $\boldsymbol{P}$ \\
\hline Among morphs & 70.621 & 4.00944 & 35.48 & 0.001 \\
Within morphs & 269.815 & 7.29230 & 64.52 & 0.00098 \\
\hline \multirow{2}{*}{ Source of variation } & Sum of squares & AMOVA: geographic groups & & \\
\hline Among geographic groups & 170.961 & 5.13057 & 50.72 & 0.001 \\
Within geographic groups & 169.475 & 4.98455 & 49.28 & 0.001 \\
\hline
\end{tabular}

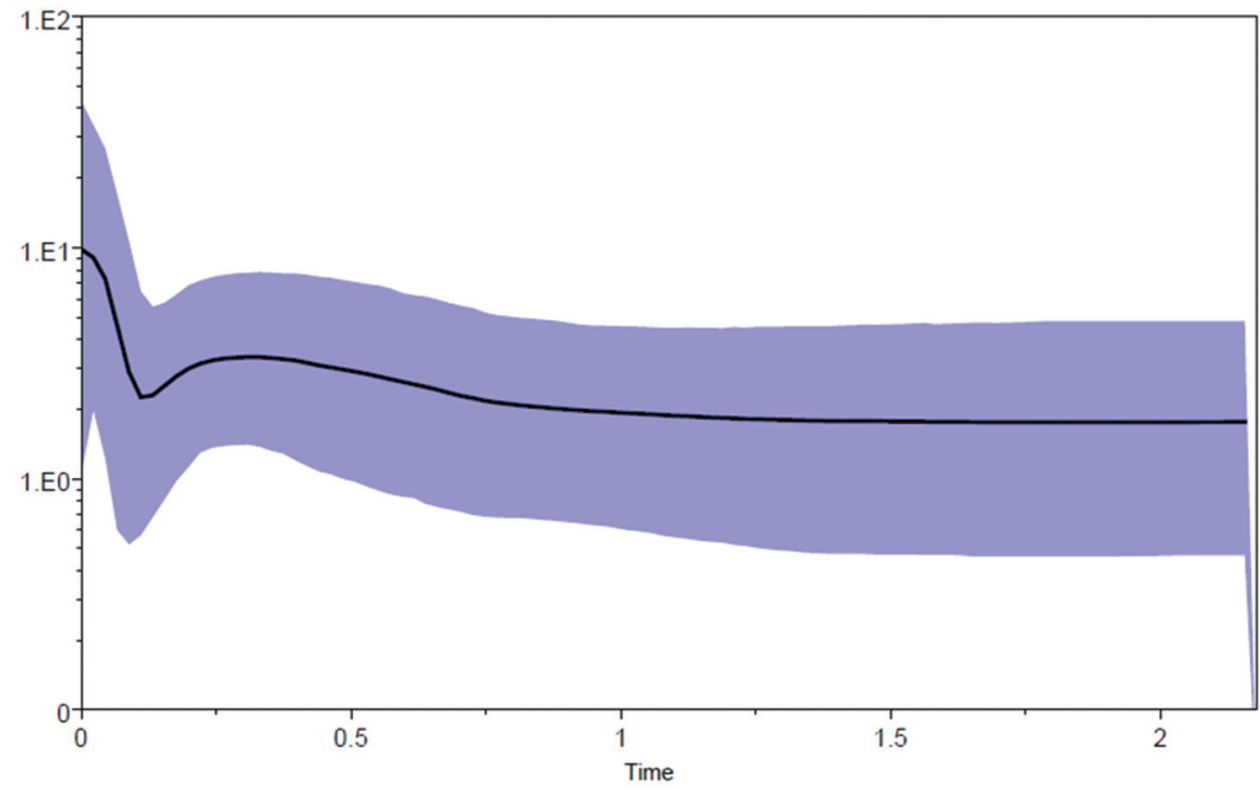

Figure 3. Bayesian skyline plot derived from the concatenated gene dataset of Atlapetes albinucha species. Time in millions of years. Population size change ( $\mathrm{Ne}^{*}$ generation time) in the $\mathrm{Y}$ axis. Mean estimate is shown as a thick solid line, and the 95\% HDP limits are shown in solid purple color area surrounding the mean estimate.

\section{Ecological niche models}

All of our ENM analyses performed better (AUC > 0.94) than a random non-predictive model (AUC $=0.5)$, indicating that the models obtained may reflect, relatively well, the past distribution of environmental conditions where A. albinucha inhabits at present. ENMs suggested a scenario of geographically fragmented environmental conditions for populations in Mexico, Central America, and Colombia during three of the modeled timeframes: LIG (ca. 120,000 ya, P-ROC, $\min =0.998$, $\max =1.972$; Figure 4d), MidHolocene $(\mathrm{MH}$, ca. 6,000 ya, P-ROC, $\min =0.997, \max =1.907$; Figure $4 \mathrm{~b})$, and for the present (Figure 4a). Present, LIG, and MH timeframes showed four main environmentally suitable areas for $A$. albinucha separated by lowlands such as the Isthmus of 
Tehuantepec, the Nicaragua Depression, and the Isthmus of Panama. In contrast, ENM for the LGM (ca. 22,000 ya, P-ROC, $\min =1.1404$, $\max =1.532$ ) suggested these same lowland areas as corridors, which may have served for the dispersal between previously isolated populations (Figure 4c), thus supporting the scenario suggested by phylogeographic patterns.

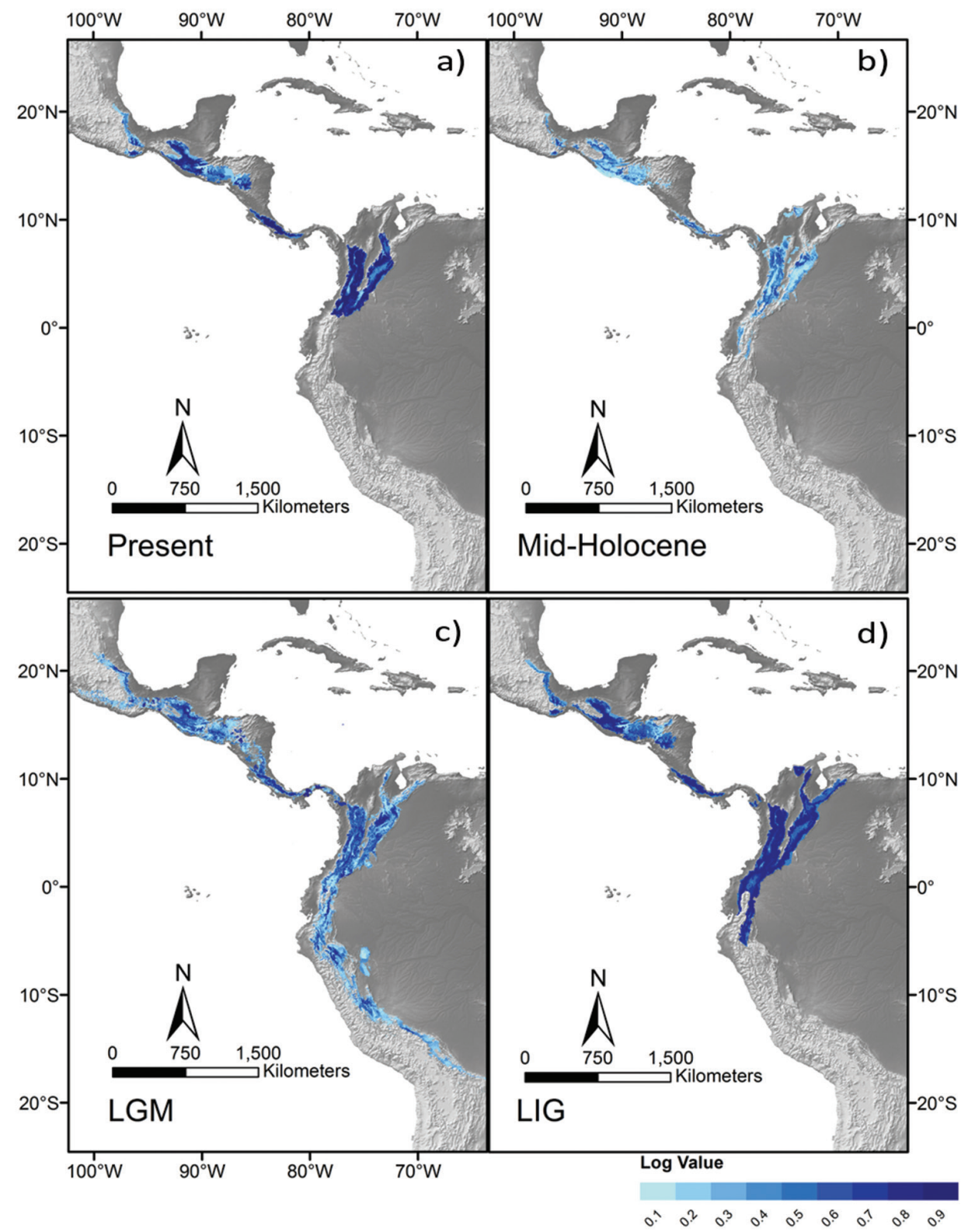

Figure 4. Maxent ENMs for $A$. albinucha species projected into present and past scenarios. Darker blue areas depict higher logistic prediction values. ENM projected in the a present $\mathbf{b}$ the Mid-Holocene Climatic Optimum (MH) c the Last Glacial Maximum (LGM) and d the Last Interglacial (LIG). 


\section{Discussion}

The major result of our analyses using mtDNA sequence data for individuals of $A$. albinucha is that this taxon exhibits an incomplete genetic differentiation along their range in the Neotropical Montane Forest. The lack of clear phylogeographic structure in this montane bird taxon is in sharp contrast with expectations based on plumage differentiation which has resulted in the recognition of up to eight subspecies (Gill and Donsker 2018) as well as to the genetic divergence found in other birds from other naturally fragmented environments throughout the Neotropics (García-Moreno et al. 2004, Cadena et al. 2007, Navarro-Sigüenza et al. 2008, Weir et al. 2008, Pérez-Emán et al. 2010, Arbeláez-Cortés and Navarro-Sigüenza 2013). Despite not recovering a clear phylogeographic structure, the geographic distribution of the genetic variation in the geography is not completely random (as indicated by AMOVA and $F_{S T}$ values), suggesting a scenario in which two groups (South America and Mesoamerica) have been diverging in isolation followed by range expansion, allowing the mixture of the genetic variation in periods favoring habitat connectivity during the LIG. Signatures for this vicariant scenario of genetic differentiation may be found in the phylogeographic topology, in which two groups including mainly South American and mainly Mesoamerican individuals were recovered, and in the significant variation among geographic groups determined by the AMOVA analyses (Table 3), as well as in the gene flow values (Table 4). Moreover, the low nucleotide diversity, but high haplotype diversity we found for mtDNA of A. albinucha, is thought to be consistent with populations passing through genetic bottlenecks followed by rapid population growth (see Grant and Bowen 1998).

The phylogeographic pattern of $A$. albinucha is consistent with allotypy, a term used to denote a stage in intermediate polyphyly (Omland et al. 2006). Allotypy is a likely intermediate stage of divergence characterized by local fixation of haplotypes on the path to reciprocal monophyly (Hudson 1990). This genetic pattern has been found in other bird species such as ducks (Peters et al. 2005, Peters and Omland 2007) and ravens (Omland et al. 2006) in the Holarctic, a raptor species in Neotropical lowlands (Johnson et al. 2007), and in passerines from Australia (Joseph and Wilke 2007) and from the Neotropical montane forests (Arbeláez-Cortés et al. 2010). For most of these cases, present distribution of the genetic diversity may reflect the retention of the genetic diversity found in the ancestor for a long time after isolation, which may have had a larger population size, thus increasing the time for some polymorphisms to be retained (Joseph and Omland 2009). Similarly, population expansion derived from populations with high effective sizes may also explain the haplotype and nucleotide diversities observed (Harpending et al. 1998, Ray et al. 2003, Ng et al. 2013, Jezkova et al. 2015).

In the case of $A$. albinucha, BSP (Figure 4) suggests a long period of population stability, with a slight increase from 750,000 to 250,000 ya, after which a relatively slight decrease in population size occurred ca. 100,000 ya. This population decrease, followed by rapid population growth and range expansion is coincident with the Last Glacial Maximum during the Late Pleistocene $(-21,000$ ya), when colder conditions may have allowed the formation of corridors between previously isolated humid montane forest 
Table 4. Population pairwise comparisons using the concatenated data set. Above the diagonal is found the number of migrants per generation estimates ( $\mathrm{Nm}$ value). Below the diagonal FST index. FST values with * depict significant values $\mathrm{p}<0.05$. Numbers depict geographic group correspondence.

\begin{tabular}{lccccc}
\hline & $\mathbf{1}$ & $\mathbf{2}$ & $\mathbf{3}$ & $\mathbf{4}$ & $\mathbf{5}$ \\
\hline 1-Northern Chiapas & & 0.70586 & 0.20016 & 0.2547 & 0.45921 \\
2-Southern Chiapas & $0.41464^{*}$ & & 10.47426 & 0.67099 & - \\
3-El Salvador & $0.71412^{*}$ & 0.04556 & & 0.24878 & - \\
4-Colombia & $0.66252^{*}$ & $0.42699^{*}$ & $0.66775^{*}$ & & 0.75137 \\
5-Honduras & 0.52126 & 0 & 0 & 0.39956 & \\
\hline
\end{tabular}

patches (Figure 4a), likely enhanced by the downward altitudinal range changes of the forest belt (Hooghiemstra et al. 2006, Gutiérrez-Rodríguez et al. 2011, Rojas-Soto et al. 2012, Ornelas et al. 2010, 2013, Ramírez-Barahona and Eguiarte 2013). Such a scenario, probably promoted gene flow between previously isolated populations (e. g., Hewitt 2000, Zink and Blackwell-Rago 2000, Weir 2006, Hooghiemstra et al. 2006, Barber and Klicka 2010, Pérez-Emán et al. 2010, Wachowiak et al. 2013, Bagley and Johnson 2014, Ornelas et al. 2016). In addition, an interesting result emerging from our ENM is that regions inhabited by yellow-plumaged and grey-plumaged populations in Chiapas-Guatemala have apparently never been isolated, which seems to support conclusions by Paynter $(1972,1978)$ regarding the weakness of a low river valley as an effective barrier in separating these populations.

Causes of differentiation in plumage coloration in A. albinucha remain elusive in our analysis, as both plumage coloration patterns appeared intermixed in the tree topology, which suggest different processes for the configuration of the genetic variation and the phenotypic plumage differentiation. Therefore, the clear phenotypic differentiation between yellow-colored birds in northern Chiapas and gray-colored birds in the rest of the distributional range suggests that plumage may be under natural selection. Similar results have been obtained for other groups of birds in different geographical and ecological settings, such as in the Tropical Pacific islands (Filardi and Smith 2005, Uy et al. 2009), shorebirds (Rheindt et al. 2011), and Australian woodswallows (Joseph et al. 2006). In the case of Atlapetes brushfinches, yellow- and gray-plumage patterns are apparently ecologically segregated from each other at different elevations. Gray-plumaged birds tend to occupy high elevation, whereas yellow-plumaged birds tend to occupy lower elevations (Remsen and Graves 1995), thus suggesting that gray-plumages have evolved to deal with conditions on high elevations, but also some dry low-elevation environments (SánchezGonzález et al. 2015). Similar changes in plumage patterns like the one detected in our study, and their correlation with environmental variables, have been also documented for other bird groups throughout the World (see Bowers 1960, Hall et al. 1966, Wunderle 1981, Galeotti and Cesaris 1996, Grunst et al. 2014, Reudnik et al. 2015). At the molecular level, plumage color changes are apparently a result of the concentration of lutein in the feather (Johnson and Brush 1972, Brush and Johnson 1976, McGraw and Hill 2006), however the specific mechanism in Atlapetes is unknown, although some studies point to single point mutations at the MCR-1 (melanocortin-1 receptor gene) as respon- 
sible for similar plumage changes in birds (reviewed in Mundy 2005, but see Cadena et al. 2011). Consistent with previous molecular-based studies, this study also supported that $\mathrm{mtDNA}$ variation does not correspond to plumage pattern differentiation in this species (Sánchez-González et al. 2015), suggesting that plumage coloration pattern in A. albinucha may be taxonomically misleading because it doesn't reflect population history. In addition, it has been shown that vocal repertories are very similar and calls between color morphs cannot be reliably differentiated (Sánchez-González et al. 2015, Boesman 2016).

Results in this paper are not conclusive in terms of the currently accepted taxonomy for $A$. albinucha. Genetic divergence as a result of allotypy is apparent, suggesting that these taxa are likely at allotypy (Omland et al. 2006). Results in other bird taxa where allotypy has been found, show support to maintain recognized species, as genetic divergence is accompanied by morphological divergence (e. g., Peters and Omland 2007, Johnson et al. 2007), whereas others advocate to a single widespread (albeit genetically differentiated) species (e. g., Peters et al. 2005, Omland et al. 2006), lending an ambiguous support for species recognition. The study of Johnson et al. (2007) offered however, a threshold for species and subspecies recognition for a Neotropical raptor. The application of such a threshold for $A$. albinucha would support a subspecific status for all populations analyzed, thus maintaining the current taxonomic treatment (Paynter 1978, AOU 1998, Gill and Donsker 2015). However, further studies should be extended to include southern Central American populations and other genetic markers. Finally, results presented here underline that a general pattern for the evolution of montane bird taxa in Mesoamerica and Northern South America should consider several exceptions like the one depicted here for $A$. albinucha, as well as emphasize the role of idiosyncratic events in the recent evolution of bird taxa in this region, as it has been suggested for lowland bird taxa (Smith et al. 2014).

\section{Conclusions}

Genetic patterns found in A. albinucha were unexpected given previous findings in birds and other taxa codistributed in montane forests throughout the region (see Ornelas et al. 2013), which in general have showed corresponding patterns of genetic and morphological divergence (e. g., García-Moreno et al. 2004, Pérez-Emán et al. 2010).

The phylogeography of $A$. albinucha is consistent with allotypy, which has been suggested to represent an intermediate stage in the path to reciprocal monophyly (Omland et al. 2006). Most cases of allotypy have been reported in temperate birds from Eurasia (Peters et al. 2005, Omland et al. 2006, Peters and Omland 2007) as well as in the Eremian birds from Australia (Joseph and Wilke 2007), as well as in the Neotropics (see also Arbeláez-Cortés et al. 2010).

Environmental factors may have played a major role in shaping the evolution of morphological traits by natural selection that have been considered taxonomically relevant (Ball and Avise 1992), such as coloration pattern seen across the entire lineage (Paynter 1972, 1978, Remsen and Graves 1995, Sánchez-González et al. 2015), but that are not congruent with the genetic divergence indicated by mtDNA. 


\section{Acknowledgements}

This contribution is part of AR-M Undergraduate Thesis and was supported by a scholarship from PAPIIT. Financial support was obtained from CONACyT 152060 and PAPIIT 215515 to AGN-S, and from Vicerrectoría de Investigación y Extensión of Universidad Industrial de Santander, Colombia, under Grant Proyecto de investigación capital semilla 2300 to EA-C. We thank the University of Kansas (M. B. Robbins \& A. T. Peterson), the Colección de Tejidos del Instituto de Investigación de Recursos Biológicos "Alexander von Humboldt", and the Museo de Zoología de la Facultad de Ciencias "Alfonso L. Herrera" and their respective staff for kindly providing tissue samples used in this study; a special acknowledgment to all the scientific collectors that obtained and deposited samples and voucher specimens of $A$. albinucha in these collections. We thank Natural Earth (http://www.naturalearthdata.com) for providing the raster data that was used in this study to map our species distribution models. Logistic help was obtained from Jano Núñez, Fanny Rebón, and Alejandro Gordillo (at UNAM), and by Diana Espitia Reina and Claudia A. Medina Uribe (at IAvH). Comments to early versions of this paper were obtained from Laura Márquez, Leticia Ochoa, and Erick García-Trejo. We are deeply indebted to Jon Fjeldså and Knud Jønsson for their comments, which greatly improved our manuscript.

\section{References}

AOU (1998) Check-List of North American Birds ( $7^{\text {th }}$ edn). American Ornithologists' Union, Washington, DC, $829 \mathrm{pp}$.

Arbeláez-Cortés E, Nyári ÁS, Navarro-Sigüenza AG (2010) The differential effect of lowlands on the phylogeographic pattern of a Mesoamerican montane species (Lepidocolaptes affinis, Aves: Furnariidae). Molecular Phylogenetics and Evolution 57: 658-68. https://doi. org/10.1016/j.ympev.2010.06.013

Arbeláez-Cortés E, Navarro-Sigüenza AG (2013) Molecular evidence of the taxonomic status of western Mexican populations of Phaethornis longirostris (Aves:Trochilidae). Zootaxa 3716: 81-97. https://doi.org/10.11646/zootaxa.3716.1.7

Arbogast BS, Drovetski SV, Curry RL, Boag PT, Seutin G, Grant PR, Grant RB, Anderson DJ (2006) The origin and diversification of Galapagos mockingbirds. Evolution 60 370-382. https://doi.org/10.1111/j.0014-3820.2006.tb01113.x

Avise JC (2000) Phylogeography. Harvard University Press, Cambridge, 447 pp.

Bagley JC, Johnson JB (2014) Phylogeography and biogeography of the Lower Central American Neotropics: diversification between two continents and between two seas. Biological Reviews 89: 767-790. https://doi.org/10.1111/brv.12076

Ball RM, Avise JC (1992) Mitochondrial DNA phylogeographic differentiation among avian populations and the evolutionary significance of subspecies. Auk 109(3): 626-636.

Baldwin RA (2009) Use of Maximum Entropy Modeling in Wildlife Research. Entropy 11: 854-866. https://doi.org/10.3390/e11040854 
Bandelt HJ, Forster P, Röhl A (1999) Median-joining networks for inferring intraspecific phylogenies. Molecular Biology and Evolution 16(1): 37-48. https://doi.org/10.1093/oxfordjournals.molbev.a026036

Barber BR, Klicka J (2010) Two pulses of diversification across the Isthmus of Tehuantepec in a montane Mexican bird fauna. Proceedings of the Royal Society B 277(1694): 2675-2681. https://doi.org/10.1098/rspb.2010.0343

Barrera-Guzmán AO, Milá B, Sánchez-González LA, Navarro-Sigüenza AG (2012) Speciation in an avian complex endemic to the mountains of Middle America (Ergaticus, Aves: Parulidae). Molecular Phylogenetics and Evolution 62(3): 907-920. https://doi. org/10.1016/j.ympev.2011.11.020

Barve N (2008) Tool for Partial - ROC (ver 1.0). Biodiversity Institute, Lawrence.

Boesman P (2016) Notes on the vocalizations of White-naped Brush-finch (Atlapetes albinucha). HBW Alive Ornithological Note 364. Handbook of the Birds of the World Alive. Lynx Edicions, Barcelona. http://www.hbw.com/node/1252909 [8 February 2018]

Bonaccorso E, Navarro-Sigüenza AG, Sánchez-González LA, Townsend PA, García-Moreno J (2008) Genetic differentiation of the Chlorospingus ophthalmicus complex in Mexico and Central America. Journal of Avian Biology 39: 311-321. https://doi.org/10.1111/j.09088857.2008.04233.x

Bowers DE (1960) Correlation of variation in the wrentit with environmental gradients. Condor 62: 91-120. https://doi.org/10.2307/1365675

Brush AH, Johnson NK (1976) The evolution of colour differences between Nashville and Virginia's warblers. Condor 78: 412-414. https://doi.org/10.2307/1367707

Cadena CD, Klicka J, Ricklefs RE (2007) Evolutionary differentiation in the Neotropical montane region: Molecular phylogenetics and phylogeography of Buarremon brush-finches (Aves, Emberizidae). Molecular Phylogenetics and Evolution 44: 993-1016. https://doi. org/10.1016/j.ympev.2006.12.012

Cadena CD, Cheviron ZA, Funk WC (2011) Testing the molecular and evolutionary causes of a 'leapfrog' pattern of geographical variation in coloration. Journal of Evolutionary Biology 24: 402-14. https://doi.org/10.1111/j.1420-9101.2010.02175.x

Cortés-Rodríguez N, Hernández-Baños BE, Navarro-Sigüenza AG, Omland KE (2008) Geographic variation and genetic structure in the Streak-Backed Oriole: Low mitochondrial DNA differentiation reveals recent divergence. The Condor 110(4): 729-739. https://doi. org/10.1525/cond.2008.8578

Crandall KA, Templeton AR (1996) Applications of intraspecific phylogenetics. In: Harvey PH, Leigh Brown AJ, Maynard Smith J, Nee S (Eds) New Uses for New Phylogenies. Oxford University Press, Oxford, 81-99.

DaCosta JM, Spellman GM, Escalante P, Klicka J (2009) A molecular systematic revisión of two historically problematic songbird clades: Aimophila and Pipilo. Journal of Avian Biology 40: 206-216. https://doi.org/10.1111/j.1600-048X.2009.04514.x

del Hoyo J, Elliott A, Christie DA (2011) Handbook of the Birds of the World, Volume 16: Tanagers to New World Blackbirds. Lynx Editions, Barcelona, 800 pp.

Drovetsky SV, Zink RM, Fadeev IV, Nesterov EV, Koblik EA, Red'kin YA, Rohwer S (2004) Mitochondrial phylogeny of Locustella and related genera. Journal of Avian Biology 35(2): 105-110. https://doi.org/10.1111/j.0908-8857.2004.03217.x 
Drummond AJ, Suchard MA, Xie D, Rambaut A (2012) Bayesian phylogenetics with BEAUTi and the BEAST 1.7. Molecular Biology and Evolution 29: 1969-1973. https://doi. org $/ 10.1093 / \mathrm{molbev} / \mathrm{mss} 075$

Dwight J, Griscom L (1921) A Revision of Atlapetes gutturalis with Descriptions of Three New Races. American Museum Novitates 16: 1-4.

ESRI (2010) ArcGIS Desktop. Environmental Systems Research Institute, Redlands.

Excoffier L, Laval G, Schneider S (2005) Arlequin ver 3.0: An integrated software package for population genetics data analysis. Evolutionary Bioinformatics Online 1: 47-50. https:// doi.org/10.1177/117693430500100003

Fernández-Mazuecos M, Vargas P (2013) Congruence between distribution modelling and phylogeographical analyses reveals Quaternary survival of a toadflax species (Linaria elegans) in oceanic climate areas of a mountain ring range. New Phytologist 198: 1274-1289. https://doi.org/10.1111/nph.12220

Filardi CE, Smith CE (2005) Molecular phylogenetics of monarch flycatchers (genus Monarcha) with emphasis on Solomon Island endemics. Molecular Phylogenetics and Evolution 37(3): 776-788. https://doi.org/10.1016/j.ympev.2005.02.007

Fu YX (1997) Statistical Tests of Neutrality of Mutations Against Population Growth, Hitchhiking and Background Selection. Genetics 147: 915-925.

Galeotti P, Cesaris C (1996) Rufous and gray colour morphs in the Italian Tawny Owl: Geographical and environmental influences. Journal of Avian Biology 27: 15-20. https://doi. org/10.2307/3676956

García-Moreno J, Fjeldså J (1999) A re-evaluation of species limits in the genus Atlapetes based on mtDNA sequence data. Ibis 141: 199-207. https://doi.org/10.1111/j.1474919X.1999.tb07542.x

García-Moreno J, Navarro-Sigüenza AG, Townsend-Peterson A, Sánchez-González LA (2004) Genetic variation coincides with geographic structure in the common Bush-tanager (Chlorospingus ophthalmicus) complex from Mexico. Molecular Phylogenetics and Evolution 33: 186-196. https://doi.org/10.1016/j.ympev.2004.05.007

GBIF Secretariat (2015) GBIF Backbone Taxonomy. http://www.gbif.org/species/2491453 [2015-07-10]

Gernhard T (2008) The conditioned reconstructed process. Journal of Theoretical Biology 253: 769-778. https://doi.org/10.1016/j.jtbi.2008.04.005

Gill F, Donsker D (2015) IOC Bird World List (Version 5.2). [updated 2015-04-23]

Gill F, Donsker D (2018) IOC World Bird List (Version 8.2). https://doi.org/10.14344/IOC. ML.8.2

Grant WS, Bowen BW (1998) Shallow population histories in deep evolutionary lineages of marine fishes: Insights from sardines and anchovies and lessons for conservation. Journal of Heredity 89(5): 415-426. https://doi.org/10.1093/jhered/89.5.415

Grunst AS, Salgado-Ortiz J, Rotenberry JT, Grunst ML (2014) Phaeomelanin-and carotenoid-based pigmentation reflect oxidative status in two populations of the yellow warbler (Setophaga petechia). Behavioral Ecology and Sociobiology 68: 669-80. https://doi. org/10.1007/s00265-013-1681-8

Gutiérrez-Rodríguez C, Ornelas JF, Rodríguez-Gómez F (2011) Chloroplast DNA phylogeography of a distylous shrub (Palicourea padifolia, Rubiaceae) reveals past fragmentation and 
demographic expansion in Mexican cloud forests. Molecular Phylogenetics and Evolution 61: 603-615. https://doi.org/10.1016/j.ympev.2011.08.023

Hackett SJ (1996) Molecular phylogenetics and biogeography of tanagers in the genus Ramphocelus (Aves). Molecular Phylogenetics and Evolution 5(2): 368-382. https://doi. org/10.1006/mpev.1996.0032

Hall BP, Moreau RE, Galbraith CJ (1966) Polymorphism and parallelism in the african bushshrikes of the genus Malaconotus (including Chlorophoneus). Ibis 108: 161-162. https:// doi.org/10.1111/j.1474-919X.1966.tb07266.x

Harrison SP, Bartlein PJ, Brewer S, Prentice IC, Boyd M, Hessler L, Holmgren K, Izumi K, Willis K (2014) Climate model benchmarking with glacial and mid-Holocene climates. Climate Dynamics 43: 671-688. https://doi.org/10.1007/s00382-013-1922-6

Harpending HC, Batzer MA, Gurven M, Jorde LB, Rogers AR, Sherry ST (1998) Genetic traces of ancient demography. Proceedings of the National Academy of Sciences 95(4): 1961-1967. https://doi.org/10.1073/pnas.95.4.1961

Hartl DL, Clark AG (1997) Principles of Population Genetics (Vol. 116). Sinauer Associates, Sunderland, $542 \mathrm{pp}$.

Hewitt G (2000) The genetic legacy of the Quaternary Ice Ages. Nature 405(6789): 907-913. https://doi.org/10.1038/35016000

Hijmans RJ, Cameron SE, Parra JL, Jones PG, Jarvis A (2005) Very high resolution interpolated climate surfaces for global land areas. International Journal of Climatology 25: 1965-1978. https://doi.org/10.1002/joc.1276

Ho SY, Shapiro B (2011) Skyline-plot methods for estimating demographic history from nucleotide sequences. Molecular Ecology Resources 11(3): 423-434. https://doi.org/10.1111/ j.1755-0998.2011.02988.x

Hooghiemstra H, Wijninga VM, Cleef AM (2006) The paleobotanical record of Colombia: implications for biogeography and biodiversity. Annals of the Missouri Botanical Garden 93(2): 297-325. https://doi.org/10.3417/0026-6493(2006)93[297:TPROCI]2.0.CO;2

Houston DD, Shiozawa DK, Tilston Smith B, Riddle BR (2014) Investigating the effects of Pleistocene events on genetic divergence within Richardsonius balteatus, a widely distributed western North American minnow. BMC Evolutionary Biology 14: 111. https://doi. org/10.1186/1471-2148-14-111

Howell SNG, Webb S (1995) A guide to The Birds of Mexico and Northern Central America. Oxford University Press, 1010 pp.

Hudson RR (1990) Gene genealogies and the coalescent process. Oxford Surveys in Evolutionary Biology 7: 1-44.

Jezkova T, Riddle BR, Card DC, Schield DR, Eckstut ME, Castoe TA (2015) Genetic consequences of postglacial range expansion in two codistributed rodents (genus Dipodomys) depend on ecology and genetic locus. Molecular Ecology 24: 83-97. https://doi.org/10.1111/mec.13012 Johnson NK, Brush AH (1972) Analysis of polymorphism in the Sooty-capped Bush-tanager. Systematic Zoology 21: 245-26. https://doi.org/10.2307/2412163

Johnson JA, Thorstrom R, Mindell DP (2007) Systematics and conservation of the hook-billed kite including the island taxa from Cuba and Grenada. Animal Conservation 10: 349-59. https://doi.org/10.1111/j.1469-1795.2007.00118.x 
Joseph L, Wilke T, Ten Have J, Chesser TR (2006) Implications of mitochondrial DNA polyphyly in two ecologically undifferentiated but morphologically distinct migratory birds, the masked and white-browed woodswallows Artamus spp. of inland Australia. Journal of Avian Biology 37: 625-36. https://doi.org/10.1111/j.09088857.2006.03767.x

Joseph L, Wilke T (2007) Lack of phylogeographic structure in three widespread Australian birds reinforces emerging challenges in Australian historical biogeography. Journal of Biogeography 34: 612-24. https://doi.org/10.1111/j.1365-2699.2006.01635.x

Joseph L, Omland KE (2009) Rowley Review. Phylogeography: its development and impact in Australo-Papuan ornithology with special reference to paraphyly in Australian birds. Emu 2009 109: 1-23. https://doi.org/10.1071/MU08024

Klicka J, Burns K, Spellman GM (2007) Defining a monophyletic Cardonalini: A molecular perspective. Molecular Phylogenetics and Evolution 45: 1014-1032. https://doi. org/10.1016/j.ympev.2007.07.006

Kocher TD, Thomas WK, Meyer A, Edwards SV, Paabo S, Villablanca FX, Wilson AC (1989) Dynamics of Mitochondrial DNA Evolution in Animals: Amplification and Sequencing with Conserved Primers. Proceedings of the National Academy of Sciences 86: 61966200. https://doi.org/10.1073/pnas.86.16.6196

Lanfear R, Calcott B, Ho SYW, Guindon S (2012) PartitionFinder: Combined Selection of Partitioning Schemes and Substitution Models for Phylogenetic Analyses. Molecular Biology and Evolution 29(6): 1695-1701. https://doi.org/10.1093/molbev/mss020

Lovette IJ (2004) Mitochondrial dating and mixed support for the " $2 \%$ rule" in birds. Auk 121: $1-6$.

McGraw KJ, Hill GE (2006) Mechanics of carotenoid-based coloration. Bird coloration Vol 1: $177-242$.

Mendoza-González G, Martínez ML, Rojas-Soto O, Téllez-Valdés O, Arias-Del Razo I (2016) Priority areas for conservation of beach and dune vegetation of the Mexican Atlantic coast. Journal for Nature Conservation 33: 25-34. https://doi.org/10.1016/j.jnc.2016.04.007

Mundy NI (2005) A window on the genetics of evolution: MC1R and plumage colouration in birds. Proceedings of the Royal Society B 272: 1633-1640. https://doi.org/10.1098/ rspb.2005.3107

Navarro-Sigüenza AG, Peterson AT (2004) An Alternative Species Taxonomy of the Birds of Mexico. Biota Neotropica 4(2): 1-32.

Navarro-Sigüenza AG, Peterson AT, Nyari A, García-Deras GM, García-Moreno J (2008) Phylogeography of the Buarremon brush-finch complex (Aves, Emberizidae) in Mesoamerica. Molecular Phylogenetics and Evolution 47: 21-35. https://doi.org/10.1016/j. ympev.2007.11.030

Ng KW, Pointing SB, Dvornyk V (2013) Patterns of nucleotide diversity of the IdpA circadian gene in closely related species of cyanobacteria from extreme cold deserts. Applied and Environmental Microbiology 79(5): 1516-1522. https://doi.org/10.1128/AEM.03439-12

Omland KE, Baker JM, Peters JL (2006) Genetic signatures of intermediate divergence: population history of Old and New World Holarctic ravens (Corvus corax). Molecular Ecology 15: 795-808. https://doi.org/10.1111/j.1365-294X.2005.02827.x 
Ornelas JF, Ruiz-Sánchez E, Sosa V (2010) Phylogeography of Podocarpus matudae (Podocarpaceae): pre-quaternary relicts in northern Mesoamerican cloud forests. Journal of Biogeography 37: 2384-2396. https://doi.org/10.1111/j.1365-2699.2010.02372.x

Ornelas JF, Sosa V, Soltis DE, Daza JM, González C, Soltis PS, Gutiérrez-Rodríguez C, Espinosa de los Monteros A, Castoe TA, Bell C, Ruiz-Sánchez E (2013) Comparative phylogeographic analyses illustrate the complex evolutionary history of threatened cloud forests of northern Mesoamerica. PLoS ONE 8: e56283 https://doi.org/10.1371/journal.pone.0056283

Ornelas JF, González C, Hernández-Baños BE, García-Moreno J (2016) Molecular and iridescent feather reflectance data reveal recent genetic diversification and phenotypic differentiation in a cloud forest hummingbird. Ecology and Evolution 6: 1104-1127. https://doi. org/10.1002/ece3.1950

Ortiz-Ramírez MF, Andersen MJ, Zaldívar-Riverón A, Ornelas JF, Navarro-Sigüenza AG (2016) Geographic isolation drives divergence of uncorrelated genetic and song variation in the Ruddy-capped Nightingale-Thrush (Catharus frantzii; Aves: Turdidae). Molecular Phylogenetics and Evolution 94(Pt A): 74-86. https://doi.org/10.1016/j.ympev.2015.08.017

Paynter RA (1972) Biology and evolution of the Atlapetes schistaceus species-group (Aves: Emberizinae). Bulletin of the Museum of Comparative Zoology 148: 297-320.

Paynter RA (1978) Biology and Evolution of the avian genus Atlapetes (Emberizinae). Bulletin of the Museum of Comparative Zoology 148: 323-369.

Pérez-Emán JL, Mumme RL, Jablonski PG (2010) Phylogeography and adaptive plumage evolution in Central American subspecies of the slate-throated Redstart (Myioborus miniatus). Ornithological Monographs 67: 90-102. https://doi.org/10.1525/om.2010.67.1.90

Peters JL, Gretes W, Omland KE (2005) Late Pleistocene divergence between eastern and western populations of wood ducks (Aix sponsa) inferred by the 'isolation with migration' coalescent method. Molecular Ecology 14: 3407-18. https://doi.org/10.1111/j.1365294X.2005.02618.x

Peters JL, Omland KE (2007) Population structure and mitochondrial polyphyly in North American Gadwalls (Anas strepera). Auk 124: 444-462. https://doi.org/10.1642/00048038(2007)124[444:PSAMPI]2.0.CO;2

Peterson AT, Papes M, Soberón J (2008) Rethinking receiver operating characteristic analysis applications in ecological niche modeling. Ecological Modelling 213: 63-72. https://doi. org/10.1016/j.ecolmodel.2007.11.008

Phillips SJ, Anderson RP, Schapire RE (2006) Maximum entropy modeling of species geographic distributions. Ecological Modelling 190: 231-259. https://doi.org/10.1016/j.ecolmodel.2005.03.026

Rambaut A, Suchard MA, Xie D, Drummond AJ (2014) Tracer v1.6. http://beast.bio.ed.ac. uk/Tracer

Ramírez-Barahona S, Eguiarte LE (2013) The role of glacial cycles in promoting genetic diversity in the Neotropics: the case of cloud forests during the Last Glacial Maximum. Ecology and Evolution 3(3): 725-738. https://doi.org/10.1002/ece3.483

Ray N, Currat M, Excoffier L (2003) Intra deme Molecular Diversity in Spatially Expanding Populations. Molecular Biology and Evolution 20(1): 76-86. 
Remsen JV (1984) High incidence of "leapfrog" pattern of geographic variation in Andean birds: implications for the speciation process. Science 224(4645): 171-173. https://doi. org/10.1126/science.224.4645.171

Remsen JV, White Solomon Graves IV (1995) Distribution patterns and zoogeography of Atlapetes brush-finches (Emberizinae) of the Andes. The Auk 112: 210-224. https://doi. org/10.2307/4088780

Remsen JV, Areta JIJr, Cadena CD, Jaramillo A, Nores M, Pacheco JF, Robbins MB, Stiles FG, Stotz DF, Zimmer KJ (2015) A Classification of the Bird Species of South America. American Ornithologists' Union. http://www.museum.Isu.edu/-Remsen/SACCBaseline.html

Rheindt FE, Székely T, Edwards SV, Lee PLM, Burke T, et al. (2011) Conflict between Genetic and Phenotypic Differentiation: The Evolutionary History of a "Lost and Rediscovered" Shorebird. PLoS ONE 6(11): e26995. https://doi.org/10.1371/journal.pone.0026995

Ricklefs RE, Latham RE (1992) Intercontinental correlation of geographical ranges suggests stasis in ecological traits of relict genera of temperate perennial herbs. The American Naturalist 139: 1305-1321. https://doi.org/10.1086/285388

Rojas-Soto O, Sosa V, Ornelas JF (2012) Forecasting cloud forest in eastern and southern Mexico: conservation insights under future climate change scenarios. Biodiversity Conservation 21: 2671-2690. https://doi.org/10.1007/s10531-012-0327-x

Ronquist F, Huelsenbeck J, Teslenko M (2011) MrBayes 3.2: Efficient Bayesian phylogenetic inference and model choice across a large model space. Systematic Biology 61(3): 539542. https://doi.org/10.1093/sysbio/sys029

Sánchez-González LA, Navarro-Sigüenza AG, Krabbe NK, Fjeldså J, García-Moreno J (2015) Diversification in the Andes: the Atlapetes brush-finches. Zoologica Scripta 44(2): 135152. https://doi.org/10.1111/zsc. 12088

Silvestro D, Michalak I (2012) raxmlGUI: a graphical front-end for RAxML. Organisms Diversity \& Evolution 12(4): 335-337. https://doi.org/10.1007/s13127-011-0056-0

Smith BT, McCormack JE, Cuervo AM, Hickerson MJ, Aleixo A, Cadena CD, Pérez-Emán J, Burney CW, Xie X, Harvey MG, Faircloth BC (2014) The drivers of tropical speciation. Nature 515: 406. https://doi.org/10.1038/nature13687

Sorenson MD, Ast JC, Dimcheff DE, Yuri T, Mindell DP (1999) Primers for a PCRbased approach to mitochondrial genome sequencing in birds and other vertebrates. Molecular Phylogenetics and Evolution 12: 105-114. https://doi.org/10.1006/ mpev. 1998.0602

Stamatakis A (2006) RAxML-VI-HPC: maximum likelihood-based phylogenetic analyses with thousands of taxa and mixed models. Bioinformatics 22(21): 2688-2690. https://doi. org/10.1093/bioinformatics/btl446

Stamatakis A (2014) RAxML version 8: a tool for phylogenetic analysis and post-analysis of large phylogenies. Bioinformatics 30(9): 1312-1313. https://doi.org/10.1093/bioinformatics/btu033

Tajima F (1989) Statistical Method for Testing the Neutral Mutation Hypothesis by DNA Polymorphism. Genetics 123: 585-595. 
Thompson JD, Gibson TJ, Plewniak F, Jeanmougin F, Higgins DG (1997) The ClustalX windows interface: flexible strategies for multiple sequence alignment aided by quality analysis tools. Nucleic Acids Research 25: 4876-4882. https://doi.org/10.1093/nar/25.24.4876

Uy JA, Moyle RG, Filardi CE, Cheviron ZA (2009) Difference in plumage color used in species recognition between incipient species is linked to a single amino acid substitution in the melanocortin-1 receptor. American Naturalist 174: 244-54. https://doi. org/10.1086/600084

Wachowiak N, Boratynska K, Cavers S (2013) Geographic patterns of nucleotide diversity and population differentiation in three closely related European pine species from the Pinus mugo complex. Botanical Journal of the Linnean Society 172(2): 225-238. https://doi. org/10.1111/boj.12049

Warren DL, Seifert SN (2011) Ecological niche modeling in Maxent: the importance of model complexity and the performance of model selection criteria. Ecological Applications 21(2): 335-342. https://doi.org/10.1890/10-1171.1

Weir JT (2006) Divergent timing and patterns of species accumulation in lowland and highland neotropical birds. Evolution 60: 842-855. https://doi.org/10.1111/j.0014-3820.2006. tb01161.x

Weir JT, Bermingham E, Miller MJ, Klicka J, González MA (2008) Phylogeography of a morphologically diverse Neotropical montane species, the Common Bush-Tanager (Chlorospingus ophthalmicus). Molecular Phylogenetics and Evolution 47: 650-664. https://doi. org/10.1016/j.ympev.2008.02.004

Wright S (1931) Evolution in Mendelian populations. Genetics 16(2): 97-159.

Wright S (1978) Evolution and genetics of populations. Vol 4. Variability Within and Among Natural Populations. University of Chicago Press, 590 pp.

Wunderle J (1981) An analysis of morph ratio cline in the bananaquit (Coereba flaveola) on St. Vincent, West Indies. Evolution 35: 333-344.

Xie WG, Lewis PO, Fan Y, Kuo L, Chen MH (2011) Improving marginal likelihood estimation for bayesian phylogenetic model selection. Systematic Biology 60: 150-160. https:// doi.org/10.1093/sysbio/syq085

Yule GU (1925) A Mathematical theory of evolution based on the conclusions of Dr. J C Willis. Philosophical Transactions of the Royal Society B 213: 21-87. https://doi.org/10.1098/ rstb. 1925.0002

Zink RM, Blackwell-Rago RC (2000) Species limits and recent population history in the curve-billed thrasher. The Condor 102: 881-886. https://doi.org/10.1650/00105422(2000)102[0881:SLARPH]2.0.CO;2 